\title{
PENGARUH KEMANDIRIAN KEUANGAN DAERAH TERHADAP TINGKAT KEMISKINAN DI PROVINSI BANTEN
}

\author{
Influence of Regional Financial Independence against Poverty Rates in Banten
}

\author{
Alla Asmara dan Stannia Cahaya Suci \\ Departemen Ilmu Ekonomi, Fakultas Ekonomi dan Manajemen. Institut Pertanian Bogor \\ E-mail: allasmara@yahoo.com, stanniacahayas@gmail.com
}

\begin{abstract}
Fiscal decentralization aims to improve regional finance independency and reduce the fiscal dependency of central goverment. However, in practice, there are many areas that still rely on the assistance central finance for their regional development.This research aims to discuss the development of regional finance independency and analyze the influence of regional finance independency on poverty in Banten Province. This research uses descriptive method and panel data on 6 (six) regencies and cities in Banten Province at 2001-2011. The poverty model showed negative effect of regional finance independency on percentage of the poor and positive effect of balance fund's ratio on percentage of the poor. Income inequality index and unemployment rate have positive effect on the percentage of the poor. Evalution for the allocation of the fund balance and development policy are needed to reduce inequality of income distribution.
\end{abstract}

Keywords: local revenue, economic growth, poverty

\begin{abstract}
ABSTRAK
Desentralisasi fiskal bertujuan untuk meningkatkan kemandirian keuangan daerah dan mengurangi ketergantungan fiskal terhadap pemerintah pusat, namun pada pelaksanaannya masih banyak daerah yang bergantung pada bantuan dana pusat untuk pembangunan daerah. Penelitian membahas perkembangan kemandirian keuangan daerah dan pengaruhnya terhadap kemiskinan di Provinsi Banten. Penelitian ini menggunakan metode deskriptif dan data panel pada 6 (enam) kabupaten dan kota di Provinsi Banten tahun 2001-2011. Hasil penelitian menunjukkan kemandirian keuangan daerah berpengaruh positif terhadap peningkatan persentase penduduk miskin, sedangkan rasio Dana Perimbangan berpengaruh negatif terhadap persentase penduduk miskin, indeks ketimpangan pendapatan dan tingkat pengangguran terbuka berpengaruh positif terhadap persentase penduduk miskin.Implikasi kebijakan yang dirumuskan adalah perlunya dilakukan evaluasi kebijakan alokasi penggunaan Dana Perimbangan dan kebijakan pembangunan untuk mengurangi ketimpangan distribusi pendapatan.
\end{abstract}

Kata Kunci: Pendapatan Asli Daerah, pertumbuhan ekonomi, kemiskinan

\section{PENDAHULUAN}

Tujuan utama dari kebijakan desentralisasi adalah memberikan kewenangan yang lebih luas kepada setiap daerah untuk melakukan pembangunan sesuai potensi masing-masing daerah. Salah satu aspek penting pelaksanaan otonomi daerah adalah kemandirian daerah dalam membiayai kegiatan penyelenggaraan pemerintahan dan pembangunan melalui peningkatan potensi penerimaan daerah (Enceng et al., 2012).

Kemandirian keuangan daerah dapat diindikasikan dari rasio penerimaan Pendapatan Asli Daerah (PAD) terhadap total pendapatan daerah. Pangsa PAD terhadap total pendapatan daerah untuk seluruh kabupaten dan kotadi Provinsi Banten tahun 2001-2011 disajikan pada Gambar 1. Berdasarkan Gambar 1 diketahui bahwa sumber pendapatan 
seluruh kabupaten dan kota sebagian besar masih bersumber dari Dana Perimbangan. Pangsa Dana Perimbangan tertinggi adalah pada Kabupaten Pandeglang yaitu sebesar
88,43 persen. Sementara itu, pangsa PAD terhadap pendapatan daerah masih relatif rendah yaitu kurang dari 20 persen.

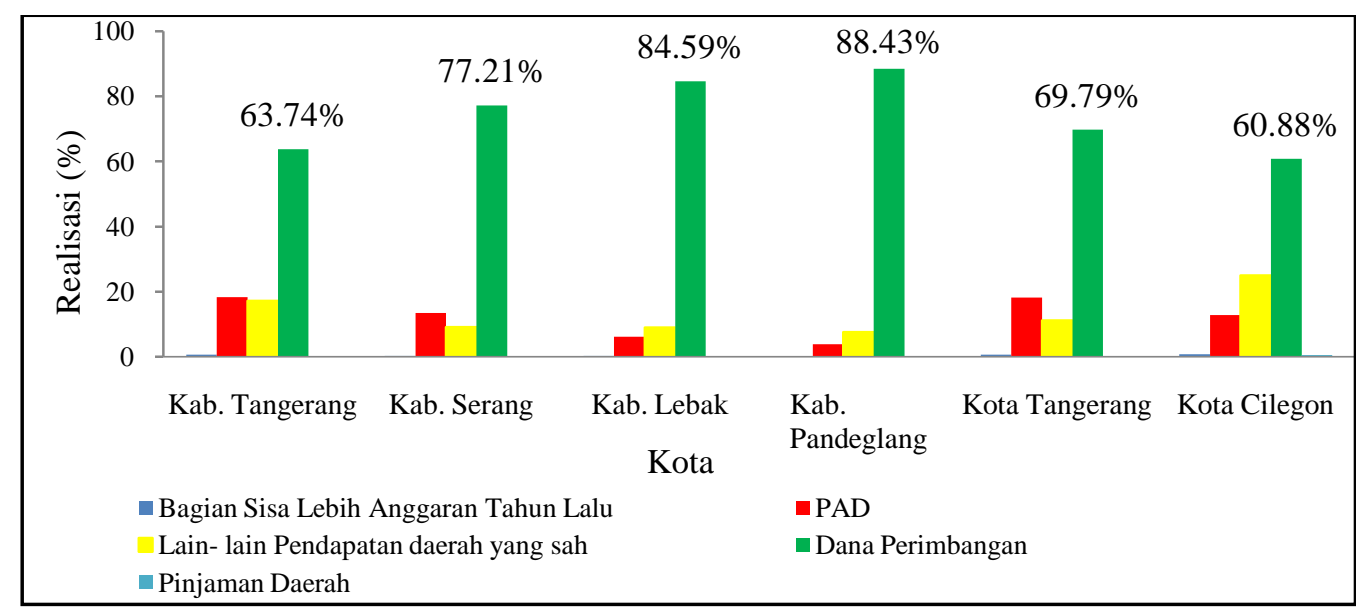

Sumber: DPKKD Banten, 2013

Gambar 1. Realisasi Pendapatan Daerah Kabupaten dan Kota Provinsi Banten Tahun 2001-2011

Kemandirian keuangan daerah merupakan salah satu factor yang diduga mempengaruhi tingkat kesejahteraan/ kemiskinan di suatu daerah. Daerah yang memiliki kemandirian keuangan yang tinggidiharapkan memiliki pertumbuhan ekonomi yang juga tinggi. Lebih lanjut, dengan pertumbuhan ekonomi yang tinggi maka kesejahteraan masyarakat menjadi lebih baik dan kemiskinanakan berkurang.

Badan Pusat Statistik Provinsi Banten (2013) mengungkapkan bahwa persentase penduduk miskin di Provinsi Banten adalah dibawah 10 persen (Tabel 1). Pada tahun 2010 persentasi penduduk miskin Provinsi Banten adalah 7,46\% kemudian menurun menjadi sebesar 6,26\%. Persentase penduduk miskin di Provinsi Banten menunjukkan perkembangan angka kemiskinan yang menurun. Namun apabila dikaji untuk setiap kabupaten/kota maka terdapat daerah yang memiliki persentase penduduk miskin yang relative tinggi. Kabupaten Pandeglang dan Lebak memiliki persentase penduduk miskin terbesar diantara kabupaten/kota lainnya yaitu masing-masing sebesar 9,2 persen dan 9,8 persen.

Berangkat dari fenomena kemiskinan yang ada dan tingkat kemandirian keuangan kabupetan/kota di Provinsi Banten, maka penelitian yang dilakukan berupaya untuk mengkaji hubungan antara kemandirian keuangan daerah dengan tingkat kemiskinan. Sejalan dengan itu, maka tujuan penelitian ini adalah menganalisis perkembangan kemandirian keuangan daerah dan pengaruhnya terhadap tingkat kemiskinan di Provinsi Banten. 
Tabel 1. Persentase Penduduk Miskin Provinsi Banten tahun 2009-2011

\begin{tabular}{lcc}
\hline \multirow{2}{*}{ Kabupaten/Kota } & $\begin{array}{c}2010 \\
2011\end{array}$ \\
\cline { 2 - 3 } & $\begin{array}{c}\text { Persentase Penduduk Miskin } \\
(\%)\end{array}$ & $\begin{array}{c}\text { Persentase Penduduk Miskin } \\
(\%)\end{array}$ \\
\hline Kabupaten Pandeglang & 11,4 & 9,8 \\
Kabupaten Lebak & 6,43 & 9,2 \\
Kabupaten Tangerang & 7,18 & 6,42 \\
Kabupaten Serang & 6,34 & 5,63 \\
Kota Tangerang & 6,88 & 6,14 \\
Kota Cilegon & 4,46 & 3,98 \\
Provinsi Banten & 7,46 & 6,26 \\
\hline
\end{tabular}

Sumber: BPS Provinsi Banten, 2013

\section{TINJAUAN PUSTAKA}

\section{Desentralisasi Fiskal}

Menurut Undang-Undang Nomor 32 Tahun 2004 tentang Pemerintahan Daerah Pasal 1 ayat 5, Otonomi daerah adalah hak, wewenang, dan kewajiban daerah otonom untuk mengatur dan mengurusi sendiri urusan pemerintahan dan kepentingan masyarakat setempat sesuai dengan peraturan perundang-undangan. Otonomi daerah ditegaskan dengan lahirnya UndangUndang Nomor 22 Tahun 1999 kemudian diperbaharui dengan Undang-Undang Nomor 32 Tahun 2004 tentang Pemerintahan Daerah.

Otonomi daerah dilaksanakan dengan azas desentralisasi, dekosentrasi dan tugas pembantuan. Desentralisasi adalah penyerahan wewenang pemerintahan oleh pemerintah daerah kepada daerah otonom untuk mengatur dan mengurus urusan pemerintahan dalam sistem Negara Kesatuan Republik Indonesia. Dekosentrasi adalah pelimpahan wewenang pemerintahan oleh pemerintah kepada gubernur sebagai wakil pemerintah dan/atau kepada instansi vertikal di wilayah tertentu. Tugas pembantuan adalah penugasan dari pemerintah kepada daerah dan/atau desa dari pemerintah provinsi kepada kabupaten/kota dan/atau desa serta pemerintah kabupaten kota kepada desa untuk melaksanakan tugas tertentu. Pemerintah daerah diberi wewenang dan keleluasaan di seluruh bidang pemerintahan, kecuali dalam bidang politik luar negeri, pertahanan keamanan, peradilan, moneter dan fiskal, agama, perencanaan nasional dan pengendalian pembangunan nasional seacara makro, dana perimbangan keuangan, sistem administrasi dan perekonomian negara, pembinaan dan pemberdayaan sumber daya manusia, pendayagunaan sumber daya alam serta teknologi tinggi yang strategis, konservasi dan standarisasi nasional.

\section{Kemiskinan}

Kemiskinan secara konseptual dapat dibedakan menjadi kemiskinan relatif dan kemiskinan absolut. Kemiskinan relatif merupakan kondisi miskin yang disebabkan karena pengaruh kebijakan pembangunan yang belum dapat menjangkau masyarakat secara merata sehingga menyebabkan ketimpangan distribusi pendapatan. Kemiskinan absolut didefinisikan sebagai kurangnya pemenuhan sumberdaya pokok untuk kesejahteraan, hal yang paling penting adalah makanan, air, perumahan, tanah, kesehatan dan pendidikan. Garis kemiskinan absolut tetap dalam hal standar hidup dan dapat membandingkan kemiskinan secara umum (Todaro dan Smith, 2006). 
Menurut penyebabnya, kemiskinan dapat dibagi menjadi kemiskinan kultural dan kemiskinan struktural. Kemiskinan kultural adalah kemiskinan yang disebabkan faktor-faktor adat dan budaya daerah tertentu yang mengikat seseorang sehingga tetap melekat dengan indikator kemiskinan. Indikator kemiskinan tersebut dapat setidaknya dikurangi dengan mengabaikan faktor adat dan budaya yang menghambat perubahan ke arah tingkat kehidupan yang lebih baik. Kemiskinan struktural merupakan kemiskinan yang disebabkan oleh kondisi struktur dan tatanan hidup yang tidak menguntungkan. Kemiskinan ini terjadi karena ketidakberdayaan seseorang atau sekelompok masyarakat yang gagal memperoleh akses untuk meningkatkan kualitas hidupnya karena tatanan sosial yang tidak adil (Badan Pusat Statistik, 2008).

$$
\text { Badan Pusat Statistik (BPS) }
$$
menggunakan pendekatan kebutuhan dasar (basic needs) untuk mengukur kemiskinan. Kemiskinan menurut strategi kebutuhan dasar (basic needs) ini merupakan ketidakmampuan dari sisi ekonomi untuk memenuhi kebutuhan makanan maupun non makanan yang bersifat mendasar. Semakin beragamnya pengukuran tingkat kemiskinan, maka World Bank mengeluarkan standar garis kemiskinan pendapatan rendah US\$ 1/hari, dengan harga internasional yang disesuaikan dengan mata uang lokal dengan purchasing power parities. Pendekatan kebutuhan dasar membagi 3 (tiga) indikator kemiskinan antara lain:

\section{Head Count Index (HCI). Head Count} Index merupakan persentase penduduk miskin yang berada di bawah garis kemiskinan atau pengukuran tingkat kemiskinan dengan menghitung jumlah orang miskin sebagai proporsi dari populasi yang disertai proverty gap.
2. Indeks Kedalaman Kemiskinan (Proverty Gap Index). Indeks Kedalaman Kemiskinan merupakan ukuran rata-rata kesenjangan pengeluaran masing-masing penduduk miskin terhadap garis kemiskinan. Nilai indeks yang tinggi menunjukan semakin jauhnya rata-rata pengeluaran penduduk dari garis kemiskinan.

3. Indeks Keparahan Kemiskinan (Proverty Severity Index). Indeks Keparahan Kemiskinan merupakan gambaran penyebaran pengeluaran diantara penduduk miskin. Tingginya nilai indeks menunjukkan tingginya ketimpangan pengeluaran diantara penduduk miskin.

Umumnya salah satu program prioritas pemerintah daerah adalah mengurangi kemiskinan, oleh karena itu tujuan desentralisasi adalah pemerintah dapat merespon lebih cepat kebutuhan masyarakat terutama kebutuhan dasar penduduk miskin. Sepulveda dan Vazques (2010) menemukan bahwa penurunan kemiskinan dan ketimpangan distribusi pendapatan merupakan dampak langsung dan tidak langsung dari adanya kebijakan desentralisasi fiskal dimana pemerintah daerah memiliki peranan penting melalui kebijakan yang terbuka dan langsung.

\section{Kemiskinan dan Ketimpangan}

Distribusi ukuran pendapatan merupakan ukuran yang paling sering digunakan oleh para ekonom. Ukuran ini secara langsung menghitung jumlah penghasilan yang diterima oleh setiap individu atau rumah tangga, cara mendapatkan penghasilan tidak dipermasalahkan. Rasio yang disebut sebagai rasio Kuznets, sering dipakai sebagai ukuran tingkat ketimpangan antara dua kelompok ekstrem, yaitu kelompok yang sangat miskin dan kelompok yang 
sangat kaya di dalam suatu negara.Metode lainnya yang lazim dipakai untuk menganalisis statistik pendapatan perorangan adalah dengan menggunakan kurva Lorenz. Kurva Lorenz memperlihatkan hubungan kuantitatif aktual antara persentase penerima pendapatan dengan persentase pendapatan total yang benar-benar diterima selama, misalnya satu tahun. Semakin jauh jarak kurva Lorenz dari garis diagonal (yang merupakan pemerataan sempurna), semakin timpang atau tidak merata distribusi pendapatannya (Todaro dan Smith, 2006).

Kasus ekstrem dari ketidakmerataan yang sempurna akan diperlihatkan oleh kurva Lorenz yang berhimpit dengan sumbu horizontal sebelah bawah dan sumbu vertikal di sebelah kanan. Oleh karena tidak ada satu daerah pun yang memperlihatkan pemerataan sempurna atau ketidakmerataan sempurna dalam distribusi pendapatannya, semua kurva Lorenz dari setiap daerah akan berada di sebelah kanan garis diagonal seperti yang ditunjukkan pada Gambar 2 . Semakin parah tingkat ketidakmerataan atau ketimpangan distribusi pendapatan suatu daerah, maka bentuk kurva Lorenznya pun akan semakin melengkung dan mendekati sumbuh horizontal bagian bawah (Todaro dan Smith, 2006).

Perangkat lain dan sangat mudah untuk mengukur derajat ketimpangan pendapatan relatif di suatu negara adalah menghitung rasio bidang yang terletak antara garis diagonal dan kurva Lorenz dibagi dengan luas separuh segi empat di mana kurva Lorenz itu berada. Rasio ini dikenal dengan koefisien Gini.Koefisien Gini adalah ukuran ketimpangan agregat yang angkanya berkisar antara nol (pemerataan sempurna) hingga satu (ketimpangan sempurna) (Todaro dan Smith, 2006).

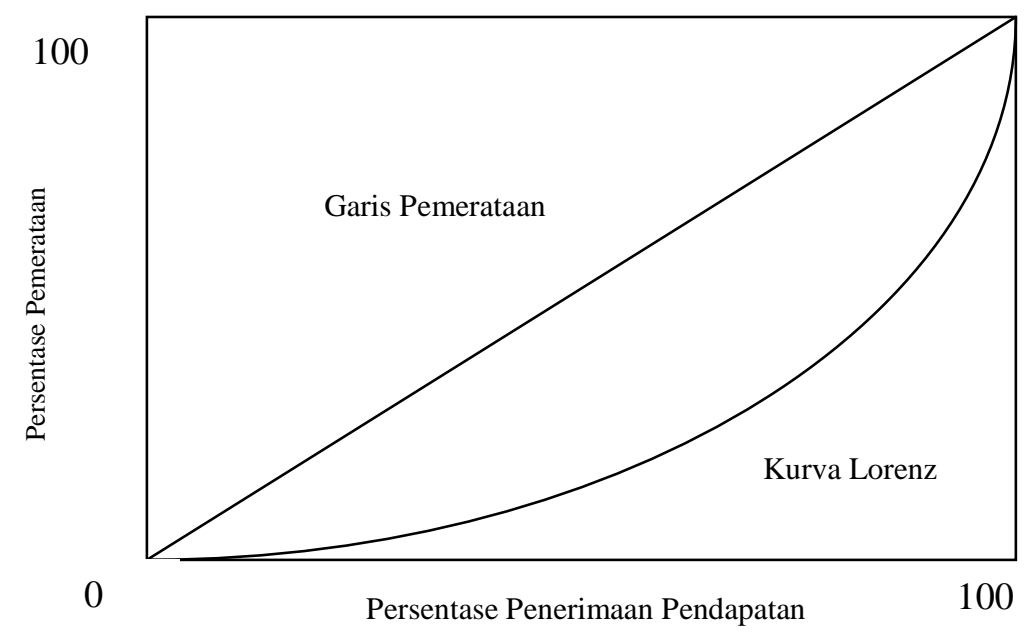

Sumber: Todaro dan Smith, 2006

Gambar 2. Kurva Lorenz

Kuznetz menyatakan bahwa pada tahap awal pertumbuhan ekonomi, distribusi pendapatan cenderung memburuk, namun pada tahap selanjutnya distribusi pendapatan akan membaik. Observasi inilah yang kemudian dikenal segaia kurva Kuznets "Uterbalik" (Gambar 3), karena perubahan longitudinal (time series) dalam distribusi pendapatan tampak seperti kurva berbentuk U-terbalik, seiring dengan naiknya pendapatan per kapita.

Dewasa ini terdapat banyak ulasan yang mencoba menjelaskan mengapa pada tahap-tahap awal pembangunan, distribusi pendapatan cenderung memburuk, namun 
kemudian membaik. Sebagian besar dari ulasan tersebut mengaitkannya dengan tahapan kondisi-kondisi dasar perubahan yang bersifat struktural. Model Lewis menyatakan tahapan pertumbuhan awal

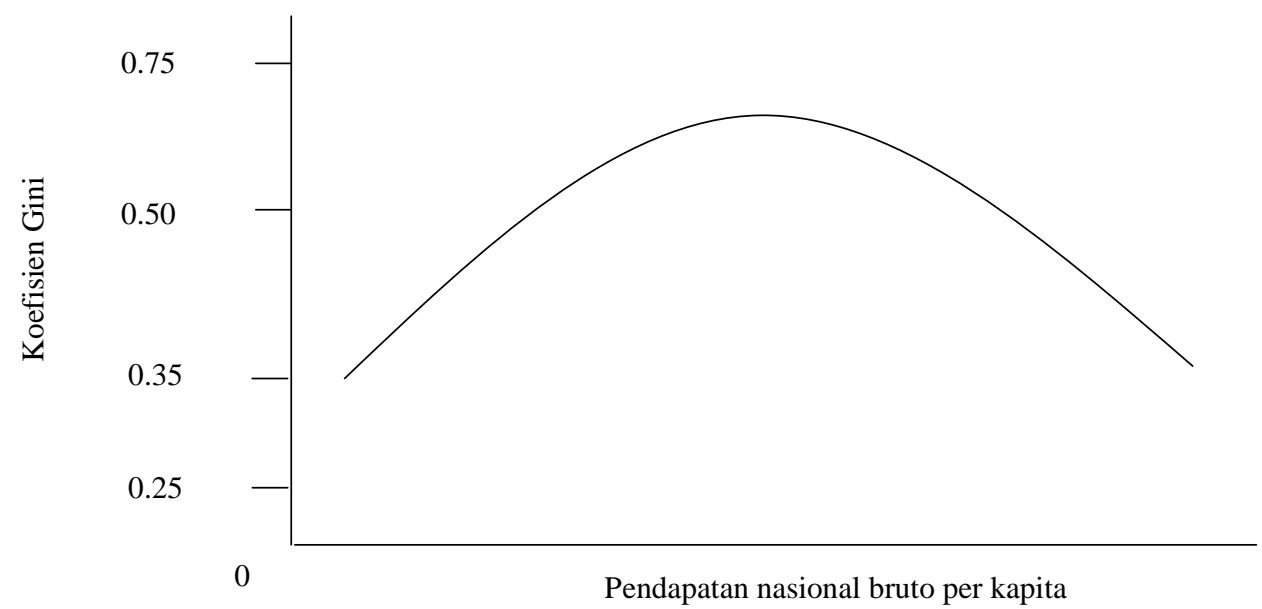

Sumber: Todaro dan Smith, 2006

Gambar 3. Kurva Kuznets U-Terbalik

Kurva Kuznets dapat dihasilkan oleh proses pertumbuhan berkesinambungan yang berasal dari perluasan sektor modern, seiring dengan perkembangan sebuah negara dari perekonomian tradisonal ke perekonomian modern. Imbalan yang diperoleh dari investasi di sektor pendidikan mungkin akan meningkat terlebih dahulu, karena sektor modern yang muncul memerlukan tenaga kerja terampil, namun imbalan ini akan menurun karena penawaran tenaga kerja terdidik akan meningkat dan penawaran tenaga kerja tidak terdidik akan menurun.

Jadi, walaupun Kuznets tidak menyebutkan mekanisme yang dapat menghasilkan kurva U-terbalik ini, secara prinsip hipotesis tersebut konsisten dengan proses bertahap dalam pembangunan ekonomi. Beberapa ekonom pembangunan berpendapat bahwa tahapan peningkatan dan kemudian penurunan ketimpangan akan terpusat di sektor industri modern yang mempunyai lapangan kerja terbatas namun tingkat upah dan produktivitas terhitung tinggi (Todaro dan Smith, 2006). tidak dapat dihindari (Todaro dan Smith, 2006).

Ketimpangan distribusi pendapatan merupakan salah satu kemiskinan yang perlu dilihat karena pada dasarnya merupakan ukuran kemiskinan relatif.Kemiskinan juga dapat digambarkan dengan koefisien Gini sebagai salah satu indikator pemerataan ekonomi. Koefisien Gini merupakan salah satu ukuran yang sering digunakan untuk mengukur tingkat ketimpangan pendapatan secara menyeluruh.

\section{METODE PENELITIAN}

Data utama yang digunakan dalam penelitian ini adalah data panel series tahunan dari tahun 2001 sampai 2011 untuk seluruh wilayah kabupetan/kota di Provinsi Banten. Data tersebut diperoleh dari BPS dan Dinas Pengelolaan Keuangan dan Kekayaan Daerah (DPKKD) Provinsi Banten. Data sekunder utama yang dihimpun adalah APBD dan data kemiskinan. Data APBD yang digunakan 
terdiri dari total pendapatan yang berasal dari PAD, Dana Perimbangan, dan Lain-lain Pendapatan Daerah yang sah.

Untuk mengukur kemandirian keuangan daerah digunakan rasio PAD (RPAD) terhadap total pendapatan daerah dan Rasio Dana Perimbangan (RDP) terhadap total pendapatan daerah. Rasio PAD terhadap total pendapatan daerah dapat mengukur kemampuan keuangan daerah. Nilai interval lebih dari 50 persen menunjukkan kemampuan keuangan daerah yang baik. Semakin besar rasio PAD terhadap total pendapatan daerah maka kemampuan keuangan daerah semakin baik. Merujuk Badan Litbang Depdagri dan Fisipol UGM maka skala interval yang digunakan seperti ditunjukkan pada Tabel 2.

Sementara itu, analisis model data panel digunakan untuk mengidentifkasi pengaruh kemandirian keuangan daerah terhadap kemiskinan kabupaten/kota di Provinsi Banten. Variabel eksogen yang diduga mempengaruhi tingkat kemiskinan meliputi: RPAD, RDP, GINI dan TP. Variabel rasio PAD (RPAD) terhadap total pendapatan daerah dan variabel rasio Dana Perimbangan (RDP) terhadap total pendapatan daerah digunakan sebagai proxy dari kemandirian keuangan daerah. Sementara itu, variabel lain yang juga terkait dengan tingkat kemiskinan adalah indeks ketimpangan distribusi pendapatan (GINI) dan tingkat pengangguran terbuka (TP) juga merupakan variabel.

Tabel 2. Interval Kemampuan Keuangan Daerah

\begin{tabular}{cc}
\hline Interval & $\begin{array}{c}\text { Kemampuan } \\
\text { Keuangan Daerah }\end{array}$ \\
\hline $00.00-10.00$ & Sangat Kurang \\
$10.01-20.00$ & Kurang \\
$20.01-30.00$ & Cukup \\
$30.01-40.00$ & Sedang \\
$40.01-50.00$ & Baik \\
$>50.00$ & Sangat Baik \\
\hline
\end{tabular}

Sumber: Depdagri dan Fisipol UGM (1991)
Formulasi model pengaruh kemandirian keuangan daerah terhadap kemiskinan kabupaten/kota di Provinsi Banten dituliskan sebagai berikut:

$$
\begin{gathered}
\text { PPM }_{\text {it }}=\alpha_{1}+\beta_{1} \text { RPAD }_{\text {it }}+\beta_{2} \text { RDP }_{\text {it }}+ \\
\beta_{3} \text { GINI }_{\text {it }}+\beta_{4} \mathbf{T P}_{\text {it }}+\varepsilon_{\text {it }} .
\end{gathered}
$$

Keterangan:

$$
\begin{aligned}
\text { PPM }= & \text { Persentase Penduduk Miskin (\%) } \\
\text { RPAD = } & \text { Rasio PAD terhadap total } \\
\text { pendapatan daerah (\%) } & \\
\text { RDP }= & \begin{array}{l}
\text { Rasio Dana Perimbangan } \\
\text { terhadap total pendapatan daerah }
\end{array} \\
& (\%) \\
\text { GINI }= & \begin{array}{l}
\text { Ketimpangan } \\
\text { Pendapatan }
\end{array}
\end{aligned}
$$
GINI $=$ Ketimpangan Distribusi Pendapatan

$\mathrm{TP}=$ Tingkat Pengangguran Terbuka (\%)

$\alpha_{\mathrm{i}} \quad=$ intersep

$\beta_{\mathrm{i}}=$ koefisien regresi

$\varepsilon_{\text {it }} \quad=\quad$ error term

$\mathrm{i}=$ kabupaten/ kota ke-i

$\mathrm{t}=$ periode waktu $(2001, \ldots, 2011)$

\section{HASIL DAN PEMBAHASAN}

\section{Perkembangan Kemandirian Keuangan Daerah}

Undang-undang Nomor 33 Tahun 2004 pasal 6 menyebutkan PAD berasal dari empat sumber yaitu Pajak Daerah, Restribusi Daerah, Hasil Pengelolaan Kekayaan Daerah yang Dipisahkan dan Lain-lain Pendapatan Asli Yang Sah. Berdasarkan proporsi realisasi PAD, Pajak Daerah memberikan proporsi terbesar terhadap PAD. Selama kurun waktu tahun 2001-2011, proporsi pajak Provinsi Banten mencapai 96,11\%, sedangkan Restribusi Daerah, Hasil Pengelolaan Kekayaan Daerah yang Dipisahkan dan Lain-lain Pendapatan yang Sah masing-masing hanya sebesar 0,19\%, 1,20\% dan 2,50\%.

Rasio PAD terhadap total 47 pendapatan daerah kabupetan/kota di 
Provinsi Banten disajikan pada Gambar 4. Berdasarkan gambar tersebut diketahui bahwa wilayah Banten Utara (Kab. Tangerang, Kota Tangerang, Kab. Serang dan Kota Cilegon) memiliki rasio PAD relatif lebih tinggi dibandingkan wilayah Banten Selatan (Kab. Pandeglang dan
Lebak). Kota Cilegon memiliki rasio PAD tertinggi dan Kabupaten Serang memiliki rasio PAD terendah di Banten Utara. Untuk wilayah Banten Selatan, Kabupaten Pandeglang dan Kabupaten Lebak memiliki rasio PAD terendah dibandingkan Kab/kota di wilayah Banten Utara.

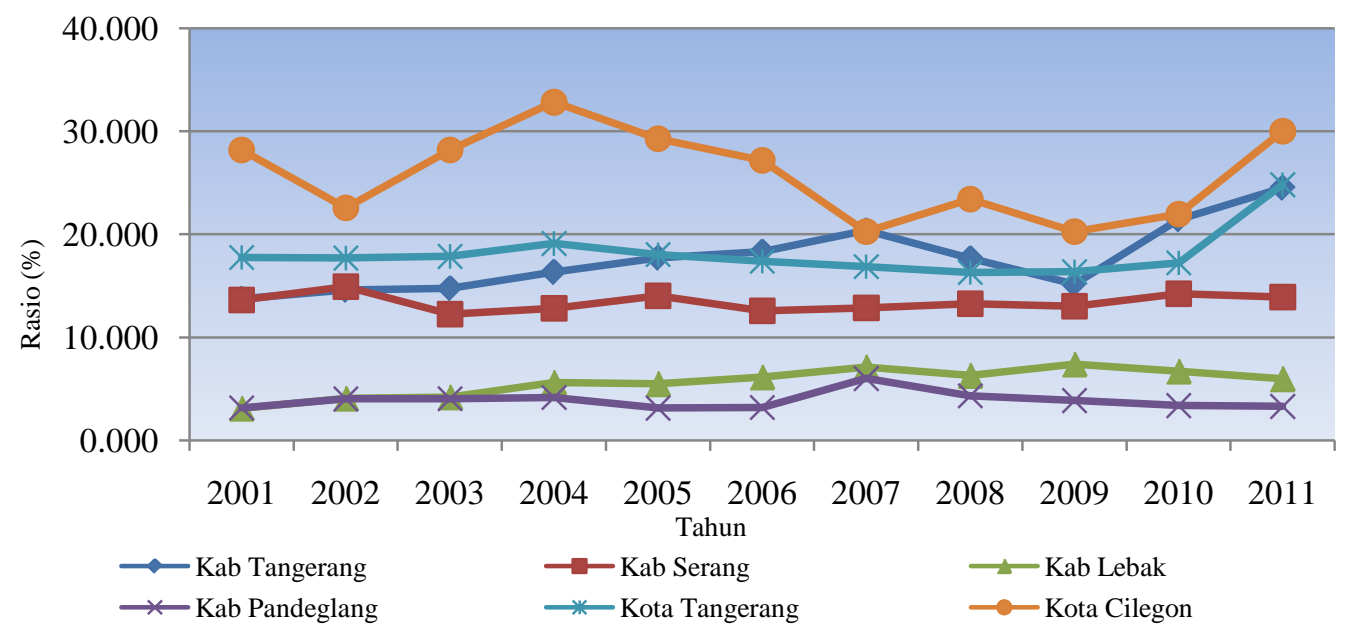

Sumber: DPKKD Banten, 2013 (diolah)

Gambar 4. Rasio Pendapatan Asli Daerah Terhadap Total Pendapatan Daerah Kabupaten Dan Kota Di Provinsi Banten Tahun 2001-2011

Rasio PAD terhadap total dan cukup menunjukkan bahwa pendapatan daerah Kabupaten Tangerang, ketergantungan fiskal pada pemerintah pusat Kabupaten Serang dan Kota Tangerang dengan rata-rata per tahunnya masingmasing sebesar $17,70 \%, 13,42 \%$ dan $18,13 \%$ jika dilihat dari interval dapat disimpulkan bahwa kemampuan keuangan daerah Kabupaten Tangerang, Kabupaten Serang dan Kota Tangerang masih kurang. Rasio PAD terhadap total pendapatan daerah Kabupaten Pandeglang dan Kabupaten Lebak dengan rata-rata setiap tahunnya hanya sebesar 3,9\% dan 5,6\% menunjukkan kemampuan keuangan daerah Kabupaten Pandeglang dan Kabupaten Lebak masih sangat kurang karena berada di interval antara $0 \%-10 \%$. Kota Cilegon dengan rasio PAD terhadap total pendapatan daerah terhadap pendapatan daerah rata-rata pertahunnya sebesar 25,83\% menunjukkan kemampuan keuangan daerah yang cukup.

Kemampuan keuangan daerah kabupaten/kota Provinsi Banten yang masih berada pada tingkat sangat kurang, kurang masih tinggi. Alokasi dana pusat kepada setiap daerah dikenal dengan dana perimbangan. Dana Perimbangan adalah dana yang bersumber dari pendapatan APBN yang dialokasikan kepada daerah untuk mendanai kebutuhan daerah dalam rangka pelaksanaan desentralisasi.

Dana Perimbangan bertujuan mengurangi kesenjangan fiskal antara pemerintah pusat dan pemerintah daerah dan antar-pemerintah daerah. Undang-undang Nomor 33 Tahun 2004 pasal 10 menyebutkan bahwa Dana Perimbangan berasal dari tiga sumber yaitu Dana Bagi Hasil, Dana Alokasi Umum dan Dana Alokasi Khusus. 


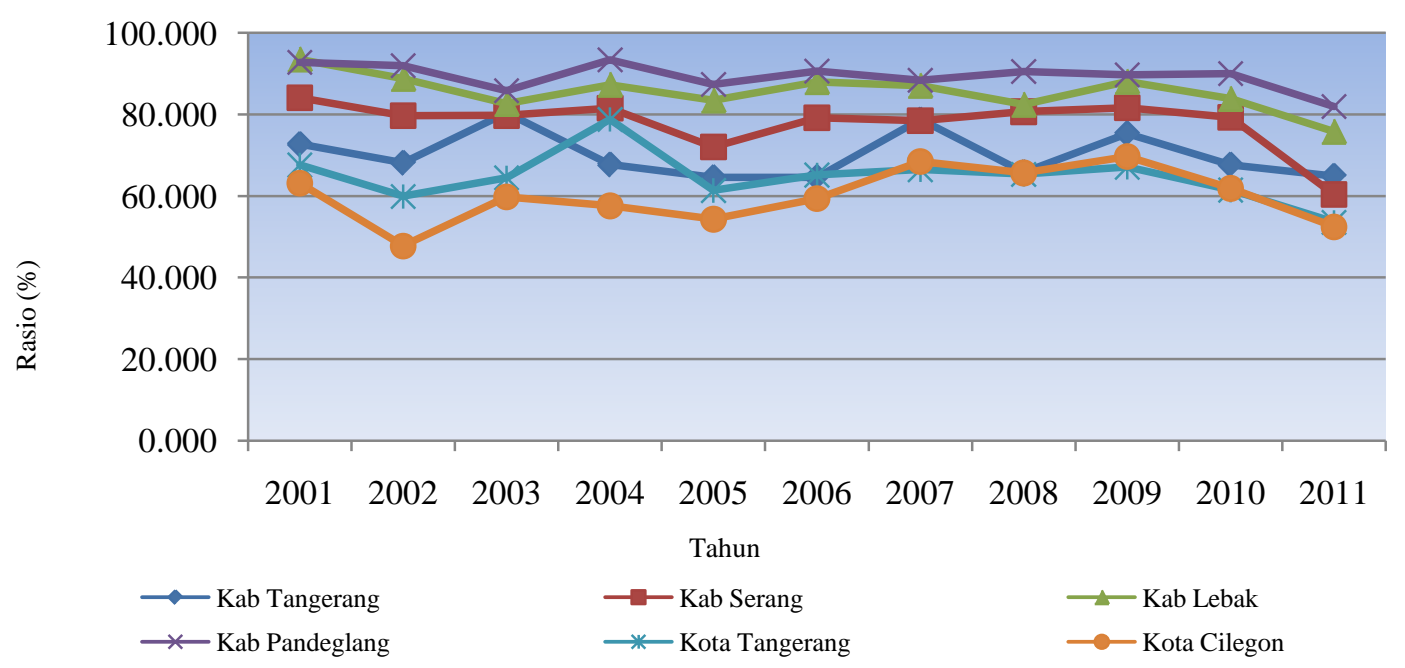

Sumber: DPKKD Banten, 2013 (diolah)

Gambar 5.Rasio Dana Perimbangan Terhadap Total Pendapatan Daerah Kabupaten Dan Kota Di Provinsi Banten Tahun 2001-2011

Perkembangan rasio dana perimbangan terhadap total pendapatan daerah kabupaten/kota di Provinsi Banten disajikkan pada Gambar 5. Kabupaten Pandeglang merupakan daerah dengan rasio dana perimbangan tertinggi yaitu sebesar 93\% pada tahun 2001 dan mengalami fluktuasi serta menurun menjadi 82\% pada tahun 2011, diikuti oleh Kabupaten Lebak pada posisi kedua tertinggi yaitu mencapai 93\% pada tahun 2001 dan menurun menjadi 76\% pada tahun 2011. Pada wilayah Banten Utara, Kota Cilegon memiliki rasio paling rendah yaitu sebesar 63\% pada tahun 2001 dan menurun menjadi 52\% pada tahun 2011, sedangkan Kabupaten Serang memiliki rasio paling tinggi yaitu sebesar $84 \%$ pada tahun 2001 dan menurun menjadi sebesar 60\% pada tahun 2011.

\section{Pengaruh Kemandirian Keuangan Daerah terhadap Kemiskinan}

Berdasarkan hasil uji Chow dan uji Hausman (Lampiran 1 dan 2) maka model panel dengan pendekatan Fixed Effect merupakan model yang digunakan untuk menganalisis pengaruh kemandirian keuangan daerah terhadap kemiskinan. Hasil estimasi faktor-faktor yang mempengaruhi kemiskinan di Provinsi Banten disajikan pada Tabel 3.

Berdasarkan Tabel 3 diketahui bahwa seluruh variabel eksogen berpengaruh signifikan terhadap kemiskinan di Provinsi Banten. Variabel RPAD, GINI dan TP berpengaruh positif terhadap tingkat kemiskinan, sedangkan variabel RDP berpengaruh negative terhadap tingkat kemiskinan.

Variabel rasio PAD terhadap total pendapatan daerah (RPAD) berpengaruh positif terhadap persentase penduduk miskin dengan koefisien sebesar 13,4631. Hal tersebut bermakna bahwa peningkatan $1 \%$ rasio PAD terhadap total pendapatan daerah akan meningkatkan persentase penduduk miskin sebesar 13,4631\%, ceteris paribus. Hal ini tidak sesuai dengan tujuan umum pelaksanaan desentralisasi fiskal dimana kemandirian keuangan daerah akan meningkatkan kinerja perekonomian daerah yang diharapkan juga akan mengurangi kemiskinan. 
Tabel 3. Hasil Estimasi Model Pengaruh Kemandirian Keuangan Daerah terhadap Kemiskinan Kabupaten/Kota di Provinsi Banten tahun 2001-2011

\begin{tabular}{ccccc}
\hline \multicolumn{1}{c}{ Variabel } & Koefisien & Std. Error & t-Statistic & Prob. \\
\hline C & 6.592286 & 0.636132 & 10.36308 & $0.0000^{*}$ \\
RPAD & 13.46312 & 1.972687 & 6.824761 & $0.0000^{*}$ \\
RDP & -10.57658 & 1.358397 & -7.786078 & $0.0000^{*}$ \\
GINI & 7.524186 & 1.274998 & 5.901334 & $0.0000^{*}$ \\
TP & 0.369451 & 0.020172 & 18.31522 & $0.0000^{*}$ \\
\hline R-squared & Weighted Statistics & Unweighted Statistics \\
Sum squared resid & 0.921158 & 0.822111 \\
Durbin-Watson stat & 62.36229 & 214.2635 \\
Prob (F-statistic) & 2.093589 & 1.892234 \\
\hline CROSSID & 0.000000 & & \\
\hline Kab Tangerang & & Effect & \\
Kab Serang & & -2.207502 & \\
Kab Lebak & & -0.411699 & \\
Kab Pandeglang & & 6.488995 & \\
Kota Tangerang & & 8.165545 & \\
Kota Cilegon & & -4.172723 & \\
\hline
\end{tabular}

Sumber: Hasil pengolahan menggunakan program Eviews6

Keterangan: *) signifikan pada taraf 5\%

Hal ini disebabkan oleh keadaan Provinsi Banten yang masih berusaha pada tahap pertumbuhan ekonomi yang tinggi, sebagaimana digambarkan dalam kurva Kuznets U-Terbalik, pendapatan nasional bruto perkapita yang terus meningkat pada tahap awal diikuti dengan peningkatan koefisien Gini. Oleh karena itu dapat diketahui mengapa peningkatan PAD yang meningkatkan pertumbuhan ekonomi dapat menambah persentase penduduk miskin.

Koefisien Gini merupakan indikator dari kemiskinan relatif. Meningkatnya koefisien Gini berarti ketimpangan pendapatan masyarakat meningkat yang dapat menambah angka kemiskinan. Hasil penelitian Nguyen (2008) juga menemukan bahwa semakin tinggi derajat desentralisasi mengurangi pendapatan penduduk miskin dan persentase penduduk miskin semakin tinggi.

Sementara itu, variabel rasio Dana Perimbangan (RDP) berpengaruh negatif terhadap persentase penduduk miskin. Artinya bahwa kenaikan 1\% rasio Dana
Perimbangan terhadap total pendapatan daerah akan menurunkan persentase penduduk miskin sebesar $10,5765 \%$, ceteris paribus. Hal ini mengindikasikan bahwa penggunaan Dana Perimbangan telah ditujukan untuk pembangunan kabupaten/ kota Provinsi Banten, terutama aspek pengurangan angka kemiskinan dan peningkatan Indeks Pembangunan Manusia (IPM) seperti alokasi dana pendidikan, belanja bantuan keuangan kepada kabupaten/kota dan pemeritah desa serta belanja bagi hasil kepada kabupaten dan kota untuk pengeluaran pembangunan. Berdasarkan Rencana Pembangunan Jangka Menengah Daerah (RPJMD) Provinsi Banten 2007-2012, pengurangan kemiskinan menjadi salah satu fokus utama pembangunan Provinsi Banten.

Variabel indeks ketimpangan pendapatan (GINI) berpengaruh positif terhadap persentase penduduk miskin. Kenaikan ketimpangan distribusi pendapatan sebesar 1\% akan meningkatkan persentase penduduk miskin sebesar $7,5241 \%$, ceteris 
paribus. Peningkatan ketimpangan distribusi pendapatan akan mengurangi kesejahteraan penduduk yang dampaknya akan menambah persentase penduduk miskin. Sejalan dengan itu, hasil estimasi juga menunjukkan variabel tingkat pengangguran terbuka (TP) berpengaruh positif terhadap persentase penduduk miskin. Kenaikan tingkat pengangguran terbuka sebesar $1 \%$ akan meningkatkan persentase penduduk miskin sebesar 0,3614\%, ceteris paribus. Tingginya angka pengangguran merupakan salah satu masalah sosial dan faktor penyebab bertambahnya penduduk miskin, karena penganggur akan menambah beban ekonomi masyarakat. Hasil estimasi menunjukkan bahwa Kabupaten Pandeglang memiliki rata-rata perubahan persentase penduduk miskin terbesar di Provinsi Banten, sedangkan Kota Cilegon memiliki rata-rata perubahan PDRB terkecil di Provinsi Banten.

\section{SIMPULAN DAN SARAN}

\section{Simpulan}

Kemandirian keuangan daerah kabupaten/kota di Provinsi Banten selama kurun waktu tahun 2001-2011 menunjukkan perkembangan semakin membaik. Namun demikian, penerimaan yang berasal dari Dana Perimbangan masih lebih tinggi daripada Pendapatan Asli Daerah (PAD). Kemampuan keuangan daerah kabupaten/kota di Provinsi Banten relative bervariasi.Kemampuan keuangan Kota Cilegon berada pada interval cukup. Untuk Kabupaten Tangerang, Kabupaten Serang dan Kota Tangerang mempunyai kemampuan keuangan yang kurang. Sementara itu, Kabupaten Pandeglang dan Kabupaten Lebak mempunyai kemampuan keuangan yang sangat kurang.

Wilayah Banten Selatan yang terdiri dari Kabupaten Pandeglang dan Kabupaten
Lebak memiliki rasio PAD yang terendah serta rasio Dana Perimbangan yang tertinggi. Hal ini menjadikankemampuan pemerintahan Kabupaten Pandeglang dan Kebupaten Lebak dalam mengurus rumah tangga dengan kemampuan sendiri menjadi sulit diwujudkan karena tidak mungkin membiayai penyelenggaraan pemerintah dengan PAD yang minim.

Berdasarkan analisis model panel disimpulkan bahwa kemandirian keuangan daerah (rasio PAD) berpengaruh terhadap peningkatan kemiskinan di Provinsi Banten. Sementara itu, Rasio Dana Perimbangan berpengaruh terhadap penurunan kemiskinan. Penelitian juga menemukan bahwa ketimpangan pendapatan daerah dan tingkat pengangguran terbuka yang tinggi akan meningkatkan kemiskinan di Provinsi Banten.

\section{Saran}

Berdasarkan kesimpulan, maka saran yang dapat diberikan adalah:

1. Kemandirian keuangan daerah kabupaten/kota di Provinsi Banten yang relative masih rendah menunjukkan bahwa masing-masing pemerintah kabupaten/kota perlu berupaya lebih keras untuk menggali potensi daerah yang dapat dikembangkan guna mendorong pertumbuhan ekonomi daerah. Disamping itu, Pemerintah Daerah perlu merumuskan kebijakan yang mendorong tumbuhnya usaha ekonomi produktif di masyarakat yang pada akhirnya dapat meningkatkan PAD. Peningkatan PAD juga dapat dilakukan dengan meningkatkan pendapatan pajak karena pajak daerah sebagai penerimaan yang paling dominan untuk penerimaan PAD.

2. Peningkatan PAD yang ternyata berpengaruh terhadap peningkatan persentase penduduk miskin 
mengindikasikan Provinsi Banten berada di tahap awal pertumbuhan ekonomi, peningkatan ekonomi diiringi dengan peningkatan ketimpangan. Ketimpangan distribusi pendapatan juga berpengaruh terhadap peningkatan kemiskinan. Oleh karena itu, kebijakan pengentasan kemiskinan yang dilakukan di Provinsi Banten perlu dilakukan secara simultan dengan kebijakan untuk mengurangi ketimpangan distribusi pendapatan.

3. Pembangunan yang dilakukan di Provinsi Banten hendaknya juga tidak hanya pada aspek fisik, tetapi juga aspek sumberdaya manusia (SDM). Peningkatan kualitas sumber daya manusia dan perluasan kesempatan kerja merupakan kebijakan yang juga dibutuhkan untuk mengatasi kemiskinan di Provinsi Banten, terutama pada wilayah Banten Selatan yang terdiri dari Kabupaten Pandeglang dan Kabupaten Lebak karena wilayah ini memiliki persentase penduduk miskin terbesar.

\section{DAFTAR PUSTAKA}

[BPPD] Badan Perencanaan Pembangunan Daerah. 2012. Rancangan Awal Rencana Pembangunan Jangka Menengah Daerah Provinsi Banten Tahun 2012-2017. Serang (ID): BPPD.

[BPS] Badan Pusat Statistik. 2013. Provinsi Banten dalam Angka Berbagai Edisi. Serang (ID): BPS.

[BPS]. Badan Pusat Statistik. 2008. Analisis dan Penghitungan Tingkat Kemiskinan 2008, katalog BPS: 3205015. Jakarta (ID): BPS

Enceng, Liestyodo, BI dan Purwaningdyah, MW. Desentralisasi Fiskal Penerimaan Keuangan Daerah. J Ilmu Administrasi Negara. 12(1):1-73.

Mahyudi, A. 2004.Ekonomi Pembangunan dan Analisis Data Empiris.Ghalia Indonesia. Bogor
Mankiw, NG. 2007. Makroekonomi Edisi Keenam. Penerbit Erlangga. Jakarta

Nguyen, HP. 2008. What is in it for the poor? Evidence from fiscal decentralization in Vietnam.Munich Personal RePec Archive.2008(9344):68-90

[RI]. Republik Indonesia. 1999. UndangUndang Republik Indonesia Nomor 22 Tahun 1999 tentang Pemerintahan Daerah. Jakarta (ID): RI

[RI]. Republik Indonesia. 1999. UndangUndang Republik Indonesia Nomor 25 Tahun 1999 tentang Perimbangan Keuangan Pemerintah Pusat dan Daerah. Jakarta (ID): RI

[RI]. Republik Indonesia. 2004. UndangUndang Republik Indonesia Nomor 32 Tahun 2004 tentang Pemerintahan Daerah. Jakarta (ID): RI

[RI]. Republik Indonesia. 2004. UndangUndang Republik Indonesia Nomor 33 Tahun 2004 tentang Perimbangan Keuangan Pemerintah Pusat dan Daerah. Jakarta (ID): RI.

Sepuvelda CF, Vazquez JM. 2010. The Consequences of Fiscal Decentralization on Poverty and Income Inequality. International Studies Program Working Paper 1002.

Tibeout, CM. 1961. An Economic Theory of Fiscal Decentralization. National Bureau of Economiz Research. 1961: 79-96

Todaro, P dan Smith SC. 2006. Pembangunan Ekonomi edisi kesembilan. Penerbit Erlangga. Jakarta Usman. 2006. Dampak desentralisasi fiskal terhadap distribusi pendapatan dan tingkat kemiskinan. Tesis.Institut Pertanian Bogor. Bogor 


\section{Lampiran 1. Hasil Uji Chow}

Redundant Fixed Effects Tests

Equation: Untitled

Test cross-section fixed effects

\begin{tabular}{lccc}
\hline \hline Effects Test & Statistic & d.f. & Prob. \\
\hline \hline Cross-section F & 33.214076 & $(5,56)$ & 0.0000 \\
\hline \hline
\end{tabular}

Lampiran 2. Uji Hausman

Correlated Random Effects - Hausman Test

Equation: Untitled

Test cross-section random effects

\begin{tabular}{lrrr}
\hline \hline Test Summary & Chi-Sq. Statistic & Chi-Sq. d.f. & Prob. \\
\hline \hline Cross-section random & 39.316243 & 4 & 0.0000 \\
\hline \hline
\end{tabular}

